\title{
DOMESTIC VIOLENCE : A QUALITATIVE STUDY IN YOGYAKARTA
}

\author{
Linda Puspita Jati'), Hermanu Joebagio ${ }^{2)}$, Hanung Prasetya ${ }^{3)}$ \\ ${ }^{1)}$ Masters Program in Public Health, Universitas Sebelas Maret \\ 2)Faculty of Social and Political Sciences, Universitas Sebelas Maret \\ ${ }^{3)}$ School of Health Polytechnics, Ministry of Health Surakarta
}

\begin{abstract}
Background: Domestic violence is any behavior the purpose of which is to gain power and control over a spouse, partner, girl/boyfriend, or intimate family member. Domestic violence is not physical violence alone. Abuse is a learned behavior, it is not caused by anger, mental problems, drugs or alcohol, or other common excuses. This study aimed to explore domestic violence in Yogyakarta, Indonesia.

Subjects and Method: This was a qualitative study with phenomenology approach. This study was conducted in non-government organization, Yogyakarta, Indonesia, in November 2018. The key informants included counsellor at the Swadaya Masyarakat Rifka Annisa Yogyakarta and two victims of domestic violence. The data were collected by in-depth interview, paticipative observation, and document review.

Results: All victims experienced domestic violence due to gender inequality in decision making. Children and wives were the most common victims of domestic violence. The domestic violence could be physical or psychic. There were various of domestic violence, but the majority stemmed from external factors. The incidence of domesic violence was affected by social environment, perceived gender equality, socioeconomic factor, and patriarchal culture. Educational background did not affect the risk of domestic violence. Conclusion: The incidence of domestic violence is affected by social environment, perceived gender equality, socioeconomic factor, and patriarchal culture.
\end{abstract}

Keywords: domestic violence, qualitative study

\section{Correspondence:}

Linda Puspita Jati. Masters Program in Public Health, Universitas Sebelas Maret, Jl. Ir. Sutami 36A, Surakarta 57126, Central Java, Indonesia. Email:

linda.puspitajati@student.uns.ac.id.

Mobile:+628543538539.

The 5th International Conference on Public Health 